\title{
Effects of Salt Concentration on Motility and Expression of Flagellin Genes in the Fish Pathogen Edwardsiella tarda
}

\author{
Jong Earn Yu, Junmo Park and Ho Young Kang*
}

Department of Microbiology, Pusan National University, Busan 609-735, Korea

Received October 19, 2011 /Revised October 25, 2011 /Accepted October 25, 2011

\begin{abstract}
E. tarda, a fish pathogen, can survive in seawater under relatively high salt conditions as well as in fish under physiological salt conditions. Bacterial growth under different salt concentrations may influence the expression of genes involved in bacterial structure and physiology. The growth rate of $E$. tarda culture in high salt $(3.5 \% \mathrm{NaCl})$ was similar to that in low salt $(1.0 \% \mathrm{NaCl}$, physiological salt concentration). Interestingly, the strain moved much faster in low salt conditions than in high salt conditions. Electron microscopic observation demonstrated that the bacterial cells grown in high salt had less or no flagellation. Obvious flagellation was observed in the parental strain E. tarda CK41 grown in low-salt condition. Two putative genes coding flagellin were identified in the E. tarda genome sequences. The amino acid sequence comparison of each gene revealed $93 \%$ identities. A flagellin gene was PCR amplified and cloned into a cloning vector. Using an E. coli protein expression system, a part of flagellin protein was overexpressed. Using the purified protein, an anti-flagellin antibody was raised in the rabbit. Immunoblot analyses with flagellin specific antibody demonstrated that E. tarda CK41 expressed falgellin in low salt conditions, which is consistent with the results seen in motility assay and microscopic observation. This is the first report of salt regulated flagella expression in E. tarda.
\end{abstract}

Key words : Edwardsiella tarda, flagella, motility, $\mathrm{NaCl}$ concentration

\section{서 론}

현재 어류 양식은 제한된 공간에서 최대의 생산을 위하여 어류를 고도로 집약하는 양식법이 발달하여 어류의 대량 생산 이 가능해 졌다. 하지만 어류의 과밀양식으로 인하여 병원체 에 의한 어류의 질병 발생률을 높이는 결과를 초래하였다[13]. 양식장 내의 한 개체가 감염성 병원체에 감염되면, 높은 밀도 로 존재하는 양식어류들에게 감염성 병원체의 빠른 전파가 가능하게 되어, 결국에는 집단폐사에 기인하여 심각한 환경 적, 경제적, 사회적 문제를 야기하게 된다[17]. 국립수산과학원 의 통계에 따르면 2004년 국내 양식 넙치의 질병 발생 현황은 세균에 의한 질병 발생률이 $41.6 \%$, 기생충에 의한 질병 발생률 이 $19.6 \%$, 바이러스에 의한 질병 발생률이 $10.8 \%$ 로 여러 병원 체 중에 세균에 의한 질병 발생률이 가장 높으며, 이러한 세균 성 질병은 주로 Aeromonas hydrophila, Streptococcus iniae, Edwardsiella tarda에 의해 발병하고 있으며, 그 중 E. tarda의 비율이 높은 편이다.

E. tarda는 통성혐기성의 그람 음성의 간균으로 어류에게 에드와드증(edwardsiellosis)이라는 질병을 유발하는 원인균 으로 알려져 있다[20]. E. tarda는 어류의 장 내, 외의 감염을

*Corresponding author Tel : +82-51-510-2266, Fax : +82-51-513-4532

E-mail : hoykang@pusan.ac.kr
위한 복잡한 장치를 가지고 있으며 피부, 항문, 장을 통하여 어류에 감염을 하고 상피세포와 대식세포와 같은 다양한 세포 로 침투하여 전신성 감염을 유발한다[23,25]. 이러한 전신 감염 성 질병의 발병은 type III 또는 VI secretion system (TTSS or T6SS)에 의해 분비되는 hemolysin, chondroitinase 및 effector 단백질과 같은 병원성 인자들과 연관되어 있다[27,28].

세균에 의한 감염성 질병에 관한 최근의 연구에 의하면 편 모, 선모, TTSS와 같은 미생물의 표면 구조물들이 초기 숙주와 의 상호작용뿐만 아니라 침투 및 집락형성에 중요한 역할을 하는 것으로 알려져 있다[2,19,26]. 편모는 어류 병원체인 Edwardsiella tarda를 포함하는 대부분의 세균에서 운동성을 담 당하는 섬유상 부속기관으로 flagellin이라는 단백질로 구성되 어 있다[14]. 편모와 운동성은 세균의 병원성과 밀접한 관련이 있기 때문에, 병원균의 환경조건에 따른 운동성의 여부를 확 인하는 것은 세균성 감염메커니즘을 이해하는데 중요한 요소 가 된다.

E. tarda는 편모 구조단백질을 암호화하는 완전한 유전자를 염색체내에 가지고 있으며, 유전체 정보 분석 결과 편모 합성 조절자인 FlhDC, class-2 편모 조절자 FliA, 편모의 회전에 필 수적인 MotA 단백질과 같은 구성요소들을 암호화하는 유전 자들을 포함하고 있다 $[5,9,24]$. 본 연구에서는 해수 $(3.5 \%)$ 와 숙 주내부 $(0.85 \%)$ 의 염농도의 차이와 같은 환경조건의 차이가 $E$. $\operatorname{tard} a$ 의 병원성 요소들 중 하나인 운동성과 편모의 발현에 미 
치는 영향을 조사, 관찰하였다.

\section{재료 및 방법}

\section{사용균주, 플라스미드, 사용배지 및 균주배양조건}

본 연구에서 사용한 Edwardsiella tarda CK41 균주는 국립 수산과학원에서 에드와드증에 걸린 넙치에서 분리한 야생균 주이다. Escherichia coli BL21 균주는 재조합 단백질의 과발현 을 위한 균주로 사용하였다. 재조합 단백질 PFAP (ㅁutative E. tarda Flagellin Associated Protein)을 발현하는 재조합 플 라스미드 $\mathrm{pBP793}$ 은 $\mathrm{pProEX}{ }^{\mathrm{TM}} \mathrm{THb}$ (Invitrogen) 발현 벡터에 $1.2 \mathrm{~kb}$ 의 EFAP DNA 단편을 클로닝하여 제조하였다. 균주는 Luria-Bertani (LB) 액체배지 또는 $1.5 \%$ agar를 첨가한 고체 배지를 사용하여 $37^{\circ} \mathrm{C}$ 에서 배양하였고, 운동성 검사를 위한 반 고체 배지는 agar농도를 $0.4 \%$ 로 바꾸어 사용하였다[3]. 해 수조건과 유사한 염농도를 위하여 $\mathrm{NaCl}$ 함유량을 $3.5 \%$ 로 추 가하여 사용하였으며, 생리적 조건의 경우 $\mathrm{NaCl}$ 함유량을 $\mathrm{LB}$ 배지와 동일하게 $(1 \%)$ 사용하였다. E. $\operatorname{tard}$ 는 모든 실험에 서 Salmonella Shigella agar 배지에서 접종하여 집락의 중앙 이 검은 특징을 형성하는지 확인하였다. 항생제가 필요할 경 우 각각의 배양조건에 ampicillin을 $100 \mu \mathrm{g} / \mathrm{ml}$ 의 농도로 첨 가하였다. 단백질 과발현을 위한 배양에서는 $600 \mathrm{~nm}$ 에서 흡 광도 0.7 까지 배양한 후 $1 \mathrm{mM}$ 의 IPTG를 첨가하여 발현을 유도하였다.

\section{일반적인 DNA 조작}

본 연구에서 이루어진 대부분의 DNA 조작은 Sambrook 등에 의해 기술된 방법에 준하여 수행하였다[15]. Rubidium chloride 용액처리법으로 제조된 E. coli competent 세포들은 heat-shock으로 형질전환 시켰다. 유전자 조작에 필요한 DNA 단편은 PCR 증폭기법을 사용하여 얻었으며, 이때 사 용된 primer는 $\mathrm{HY} 523 \mathrm{~F}$ ( $5^{\prime}$-ggatccatggcacaagtaatt $\left.-3^{\prime}\right)$ 와 HY533R (5'- aagcctttaacgcagcagaga $\left.-3^{\prime}\right)$ 이다. PCR은 다음과 같은 조건으로 수행하였다; $95^{\circ} \mathrm{C}$ 에서 30 초간 변성, primer $\mathrm{Tm}$ 값에 의한 $52^{\circ} \mathrm{C}$ 에서 30 초간 primer annealing, $72^{\circ} \mathrm{C}$ 에서 1 분간 중합반응, 그리고 $72^{\circ} \mathrm{C}$ 에서 7 분간 마지막 합성을 실시 하였다.

\section{E. tarda 균주의 생장곡선 및 생균수 측정}

E. tarda CK41을 $2 \mathrm{ml}$ 의 LB 액체배지에 각 균주의 단일 집락 을 접종하여 $37^{\circ} \mathrm{C}$ 에서 12 시간 전배양한 후, 전배양액을 $3.5 \%$ $\mathrm{NaCl}$ 또는 $1.0 \% \mathrm{NaCl}$ 을 함유하고 있는 $300 \mathrm{ml}$ 의 LB 액체배지 에 $0.1 \%$ 의 농도로 접종하여 $37^{\circ} \mathrm{C}$ 에서 $200 \mathrm{rpm}$ 의 속도로 진탕 배양하였다. 배양동안 2시간 간격으로 $600 \mathrm{~nm}$ 에서의 흡광도 를 측정하여 각 염농도 조건별로 $E$. tarda CK41의 생장을 추정 하였다. 이와 동시에 생균수 측정을 위하여 멸균된 $0.85 \%$
$\mathrm{NaCl}$ 희석수에 배양액을 10 배씩 연속적으로 희석하고 LB 고 체배지에서 배양하여 생균수를 측정하였다.

\section{E. tarda 운동성 실험}

E. tarda CK41 균주의 운동성을 관찰하기 위하여 운동성 측정배지 $(0.4 \%$ agar가 첨가된 LB배지)에서 균을 접종하여 배 양하고 그 형태를 관찰하였다. 염농도가 운동성에 미치는 영 향을 관찰하기 위하여 운동성 측정배지에 최종농도가 $1 \%$ 또 는 $3.5 \%$ 이 되도록 $\mathrm{NaCl}$ 을 첨가하였다. $2 \mathrm{ml}$ 의 $\mathrm{LB}$ 액체배지에 각 균주의 단일 집락을 접종하여 $37^{\circ} \mathrm{C}$ 에서 12 시간 전배양한 후, 염농도가 다른 운동성 측정배지의 중앙에 각 전배양액 1 $\mu \mathrm{l}$ 을 주입하여 실온에서 배양하면서 일정시간 간격으로 균주 의 운동거리를 형성된 집락의 지름을 측정하여 비교 관찰하 였다.

\section{투과 전자 현미경(Transmission Electron Microscope, TEM)}

투과 전자 현미경을 이용하여 E. tarda CK41 균주의 형태학 적 특성을 육안으로 관찰하였다. 시편 제작에 사용된 균주는 각 $3.5 \%$ 또는 $1.0 \% \mathrm{NaCl}$ 농도의 고체배지에서 자란 균체집락 을 $1 \mathrm{ml}$ 의 멸균된 $0.85 \% \mathrm{NaCl}$ 희석액에 부드럽게 현탁하여 사용하였으며, 현탁시킨 균체는 격자에 부착시키고 $1 \%$ uranyl acetate로 2분간 염색 후 TEM (Model H-7600, Hitachi, 부산대학교 공동실험실습관)을 사용하여 관찰하였다.

\section{재조합 단백질 PFAP의 과발현과 정제 및 PFAP 특이적 인 다클론성 항체의 제조}

PFAP 단백질을 대량 생산하기 위해서 대장균을 이용한 인 위적인 단백질 과발현 체계를 사용하였다. 단백질 발현을 위 한 $\mathrm{PFAP}$ 의 유전자는 E. tarda CK41 염색체 DNA를 주형으로 하여 HY532F와 HY533R primer 쌍을 이용한 PCR을 통해 1.2 $\mathrm{kb}$ 크기의 DNA단편을 증폭한 후 단백질 발현 벡터인 $\mathrm{pProEX}{ }^{\mathrm{TM}} \mathrm{HTb}$ (Invitrogen)에 삽입하여 재조합 플라스미드 $\mathrm{pBP793}$ 을 구축하였다. $\mathrm{pBP} 793$ 을 가지는 E. coli BL21을 1 $\mathrm{mM} \mathrm{IPTG}$ 가 들어있는 배양조건에서 배양하여 과량의 46 $\mathrm{kDa}$ 크기의 단백질이 발현되는 것을 SDS-PAGE를 통하여 확 인하였다. 재조합 단백질이 과발현된 E. coli BL21을 수거하여 French Pressure (Thermo Electron Cooperation)을 사용해 균 주를 파쇄하고 원심분리를 통하여 분획을 나누어 재조합 단 백질 PFAP 분획을 수거하였다. 재조합 단백질 $\mathrm{PFAP}$ 의 정제 는 $\mathrm{Ni}^{2+}$-sepharose (GE Healthcare)를 이용한 친화성 크로마 토그래피를 통해 정제하였다. 최종적으로 정제된 PFAP 단백 질은 SDS-PAGE를 통하여 단일 단백질 밴드로 확인할 수 있 었으며, 단백질의 농도를 브래드포드 방법을 사용해 정량하 였다. PFAP 특이적인 다클론성 항체를 얻기 위해서 $500 \mu \mathrm{g}$ 의 정제된 재조합 PFAP 단백질을 실험토끼(New Zealand 
White Rabbit)에 동량의 Freund's adjuvant (Sigma)와 함께 3 주 간격으로 2회 주사하였다. 실험토끼로부터 얻은 면역혈 청은 immunoblot analysis를 통하여 PFAP 단백질의 확인에 사용되었다.

\section{SDS-PAGE 및 immunoblot analysis}

단백질 시료들을 $2 \times$ digestion buffer [20\% (v/v) glycerol, $4 \%$ (w/v) SDS, 0.2\% (w/v) bromophenol blue, $200 \mathrm{mM} \beta$ -mercaptoethanol, $100 \mathrm{mM}$ Tris-HCl buffer, $\mathrm{pH} 6.8$ 에 용해하 였다 [15]. 용해된 단백질을 $95^{\circ} \mathrm{C}$ 에서 5 분간 가열한 후, 비연속 적 sodium dodecyl sulfate-polyacrylamide gel electrophoresis (SDS-PAGE)에 의해 분리하였다. 분리된 단백질은 Coomassie brilliant blue G-250 (Sigma)을 통한 염색과 탈색 으로 시각화하였다. SDS-PAGE를 통해 단백질 시료를 분리한 후 transfer 장치(BioRad)를 사용하여 단백질을 nitrocellulose membrane (BioRad)으로 이동시켰다. Towbin 등에 의해 기술 한 바와 같이 blocking solution [5\% skim milk를 함유하는 Towbin's Saline Buffer (TSB)]에서 3시간 membrane을 blocking 시킨 후, 1 차 항체를 1:400으로 blocking solution에 희석하 여 2시간 반응시켰다[21]. TBS로 수 회 세척한 membrane에 2차 항체인 peroxidase conjugated goat anti-Rabbit IgG (Sigma)를 1:1,000의 비율로 blocking solution에 희석하여 2시 간 반응시켰다. TSB로 수 회 세척한 membrane의 단백질 밴드 는 $\mathrm{H}_{2} \mathrm{O}_{2}$ (Sigma)와 4-chloro-1-naphthol (Sigma)이 포함된 용 액에서 자주색의 침착물이 생성되는 것으로 확인하고, 다량의 증류수 세척을 통하여 반응을 중지시켰다.

\section{결과 및 고찰}

\section{염농도가 E. tarda CK41의 운동성에 미치는 영향}

수온, 염농도, $\mathrm{pH}$, 숙주 스트레스상태 등과 같은 다양한 환경 인자들이 어류병원체들의 병원성에 영향을 미친다고 알려져 있다 $[1,8,10,16]$. 특히 염농도에 의한 삼투압의 변화는 병원균이 기민하게 적응해야 하는 주요한 환경 인자들 중 하 나로, 병원균은 이러한 환경 인자의 변화를 $\mathrm{EnvZ/OmpR}$ two component regulation system을 통하여 반응한다[11]. 해수어에 감염하는 어류병원체의 경우 숙주내부와 외부인 해수의 염농도가 급격하게 변하기 때문에 이러한 삼투압의 변화에 다른 병원체들과 유사한 방법으로 대응하고 있다[6]. 이러한 삼투압에 의한 반응기작은 비단 병원체의 생육에만 관여하는 것이 아니라, 병 원체의 병원성에도 관여한다는 보 고가 있다[4]. 따라서 본 연구에서 해수조건 및 생리적 조건 의 염농도에서 E. $\operatorname{tarda} \mathrm{CK} 41$ 의 주요한 병원성 인자인 운동 성에 미치는 영향을 알아보고자 하였다. 특히 편모에 의한 운동성은 주화성에 의한 방향성을 가지는 운동에 관여할 뿐 만아니라 부착과 숙주내 집락형성과정을 비롯한 병원성에서

\section{도 필수적인 요소이다[12].}

생리적 염농도 조건과 유사한 $1 \% \mathrm{NaCl}$ 을 함유하고 있는 운동성 측정배지 $(0.4 \%$ agar를 함유하는 LB 고체배지)와 해수 의 염농도와 유사한 $3.5 \% \mathrm{NaCl}$ 을 함유하는 운동성 측정배지 에 E. tarda CK41 전배양액을 접종하여 집락의 변화를 3일간 관찰하였다. 그 결과 염농도가 높은 환경에서 E. tarda CK41의 운동성이 감소하는 것을 확인할 수 있었다(Fig. 1). 생리적 조 건의 염농도에서는 매일 $3 \mathrm{~cm}$ 의 속도로 운동성을 보이는 반 면, 해수의 염농도 조건에서는 매일 $0.2 \mathrm{~cm}$ 의 속도로 운동성을 보여 생리적 조건이 해수 조건보다 속도가 15 배 빠른 것으로 나타났다. 해수조건의 염농도에서 운동성의 저하가 높은 염농 도에 의한 생육의 저해로 인한 것이 아닌지를 확인하기 위하 여 $600 \mathrm{~nm}$ 에서의 흡광도를 측정해본 결과, 해수조건의 염농도 에서 흡광도가 다소 낮은 경향을 보였다(Fig. 2A). 하지만 같은 시간간격으로 생균수를 측정해본 결과 실질적인 균수는 12 시 간 이후부터 그 차이가 $1 \log$ 이하로 매우 적은 것을 확인 할 수 있었다(Fig. $2 \mathrm{~B}$ ). 따라서 높은 염농도에서의 운동성의 감소 는 생육 정체에 의한 것이 아니고 실질적인 운동성의 차이에 의한 결과라는 것이 확인되었다.

\section{염농도에 따른 E. tarda CK41의 편모형성}

세균은 다양한 방법으로 운동성을 가지는데, 주로 편모의 회전에 의한 유영(swiming)과 비유영성의 활주(gliding) 등에 방법으로 자신의 힘으로 움직일 수 있다[18,22]. E. tarda CK41 는 염색체에 편모의 구성요소들을 가지고 있으나[24], 염농도 에 따른 운동성은 편모에 의한 것인지는 알려지지 않았다. 따 라서 다양한 염농도에서 편모의 형성 유무를 재료 및 방법에 서 기술한 방법에 의해 투과 전자 현미경을 이용하여 그 형태 학적 차이를 육안으로 관찰하였다(Fig. 3). 담수와 해수조건의 염농도에서 12 시간 배양한 $E . t a r d a C K 41$ 의 표면구조를 관찰

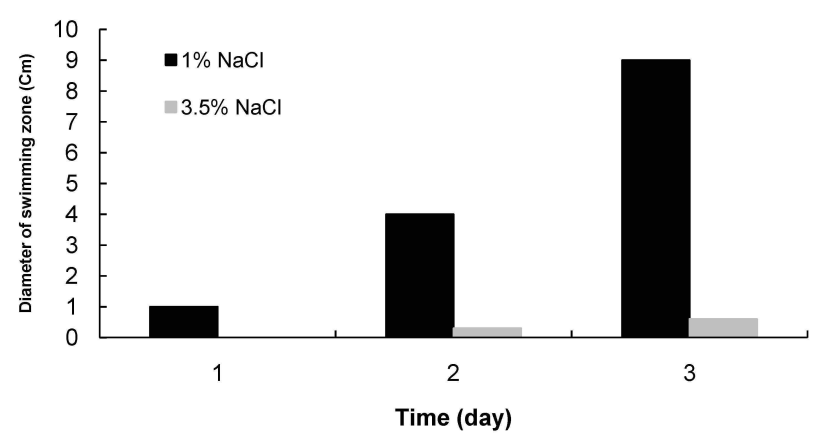

Fig. 1. Effect of $\mathrm{NaCl}$ concentration on E. tarda CK41 motility. E. tarda CK41 was inoculated in motility agar plates (LB agar containing $0.4 \%$ agar) containing concentration of $1 \% \mathrm{NaCl}$ (black bars) or $3.5 \% \mathrm{NaCl}$ (gray bars). The plates were incubated for 3 days at room temperature. Motility was assayed by measuring the diameter of swimming zone. 
A

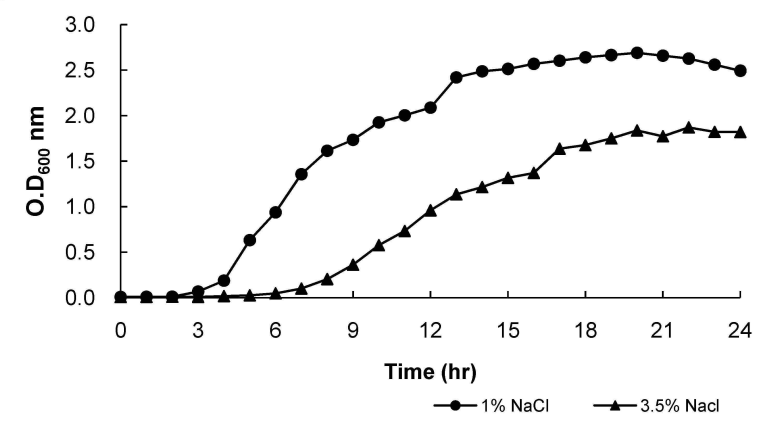

B

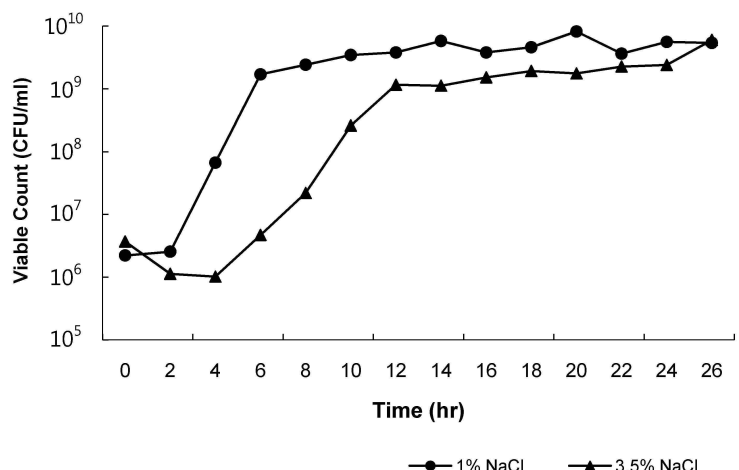

Fig. 2. Growth of $E$. tarda $\mathrm{CK} 41$ under various $\mathrm{NaCl}$ concentration. E. tarda CK41 cells were cultured in LB broth containing concentration of $1 \% \mathrm{NaCl}(\mathbf{O})$ or $3.5 \% \mathrm{NaCl}(\mathbf{\Delta})$ at $37^{\circ} \mathrm{C}$ with shaking. (A) Optical density at $600 \mathrm{~nm}$ wavelength was measured at the time points indicated in the graph. (B) Viable-cell counts were determined at the points indicated in the graph.

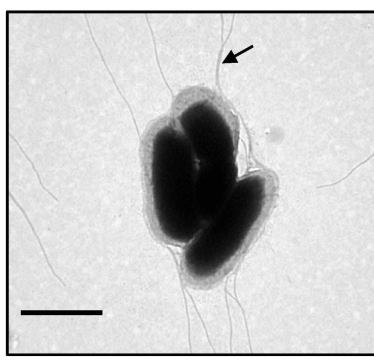

$1 \% \mathrm{NaCl}$

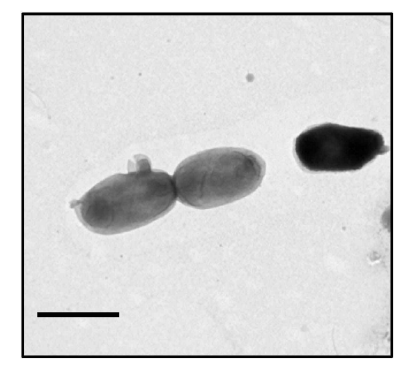

$3.5 \% \mathrm{NaCl}$
Fig. 3. Transmission electron microscope image of $E$. tarda CK41 at different $\mathrm{NaCl}$ concentration. E. tarda CK41 cells grown in agar plates containing $1 \%$ or $3.5 \% \mathrm{NaCl}$ were diluted in $0.85 \% \mathrm{NaCl}$ and dyed for two minutes on the grid with $1 \%$ uranyl acetate. The black arrow indicates flagella of $E$. tarda CK41.

한 결과, $1 \% \mathrm{NaCl}$ 에서 자란 $E . t a r d a C K 41$ 의 경우 다수의 편 모를 형성하는 것을 확인한 반면(Fig. $3 \mathrm{~A}), 3.5 \% \mathrm{NaCl}$ 의 경우 편모가 형성되지 않는 것을 확인하였다(Fig. 3B). 투과 전자 현미경 결과 편모가 염농도에 따른 운동성에 관여하는 인자
인 것을 확인할 수 있었으며, E. tarda 유전체 내에서 편모 생 성 유전자를 찾아보았다. 그람 음성 세균인 Salmonella typhimurium의 fliC 유전자 서열을 기반으로 ClustralW2 EBI alignment를 이용해 $E$. tarda의 편모 유전자를 조사해본 결과 $72 \%$ 의 상동률을 가지는 Putative E. tarda Flagellin Associated Protein (PFAP) 유전자와 74\%의 상동률을 가지 는 Flagellin Domain Protein (FDP) 유전자를 확인할 수 있었 다(Fig. 4).

\section{염농도에 따른 편모 발현의 확인}

환경조건에 따라 편모단백질의 구조가 변화하여 편모가 발 현은 하지만 외부에서 조립되지 않아 기능을 가지는 편모를 형성하지 못한다는 보고가 있다[7]. 주요한 환경조건인 염농도 에 따른 운동성의 차이가 편모의 형성에 의한 것임을 투과 전자 현미경으로 확인하였지만(Fig. 3), $3.5 \% \mathrm{NaCl}$ 조건에서의 편모의 부재가 편모 유전자의 발현이 되지 않기 때문인지, 편 모 유전자는 발현이 되지만 편모가 정상적으로 조립되지 않아 서 유지를 못하는 것인지를 알아보기 위하여 편모 유전자 특 이적인 다클론성 항체를 제작하였다. E. $\operatorname{tard}$ 는 두개의 편모 유전자(PFAP, FDP)를 가지고 있으며 이들간의 아미노산 상동 률이 $93 \%$ 로 높은 편이기 때문에, 두 개의 편모 유전자중 임으 로 선정된 PFAP에 대한 항체를 재료 및 방법에서 기술한 방법 으로 제조한 재조합 플라스미드 $\mathrm{pBP793}$ 을 대장균 발현시스템 을 이용하여 과발현하고 정제하였다.

E. $\operatorname{tarda} \mathrm{CK} 41$ 의 생리적 조건과 해수조건에서의 편모 단백 질의 발현을 알아보기 위하여 E. tarda CK41 균주를 각각 생리 적 조건과 유사한 $1 \% \mathrm{NaCl}$, 해수의 염농도와 유사한 $3.5 \%$ $\mathrm{NaCl}$ 이 첨가된 $\mathrm{LB}$ 액체배지에서 배양한 후, $\mathrm{PFAD}$ 에 특이적 인 다클론성 항체를 이용하여 immunoblot assay를 수행하여 확인하였다(Fig. 5). $1 \% \mathrm{NaCl}$ 조건에서 배양한 E. tarda CK41 균주의 경우, $3.5 \% \mathrm{NaCl}$ 에서 배양한 균주보다 많은 양의 편모 단백질이 발현되는 것을 확인 할 수 있었다. 편모 단백질 $\mathrm{PFAD}$ 와 $\mathrm{FDP}$ 의 아미노산 상동률이 높기 때문에 $\mathrm{PFAD}$ 특이 적인 다클론성 항체가 $\mathrm{PFAD}$ 뿐만 아니라 $\mathrm{FDP}$ 와 반응할 수 있다고 가정하였을 때, PFAD 특이적인 항체를 이용한 immunoblot assay의 결과에 따른 면역 활성 단백질 밴드의 양은 전체 편모 단백질의 발현양과 유사하다고 할 수 있다. 이러한 결과를 통하여 염농도가 높은 환경에서의 운동성의 감소는 E. tarda CK41의 편모가 제대로 형성되지 않고, 이것은 편모 단백질의 발현이 저해된 것이 주요한 원인인 것으로 확인되었 다. 현재 편모 유전자의 결손 돌연변이주를 구축하여 실제로 편모가 운동성에 관여하는지 여부의 확인과, 편모가 병원성인 자로서 기능을 하는지 알아보기 위한 어류 감염모델에서의 독성 검사 실험이 진행 중이다. 
PFAP atggcacaagtaat taataccaacagcctgtcgctgatggcacagaacaacctgaacaaat c c agt cagcgctgggcaccgcca 85 FDP atggcacaagtaatcaacaccaacagcctgtcgctgatggcacagaacaacctgaacaat c c agtctgcc tgggcaccgcca 85 Flic atggcacaagtcattaatacaacagcctgtcgctgttgacccagaataacctgaacaatcccagtccgctctgggcaccgcta 85 100 120 140 160

PFAP $t \mathrm{cgagcgtctgtcttccggtctgcgcatcaacagcgccaaggatgacgccgccggtcaggcgatctccaaccgcttcaccgccaa} 170$ FDP $\mathrm{tcgagcgtctgtcttccggtctgcgtatcaacagcgccaaggatgacgccgccggtcaggcgatctccaaccgct} \mathrm{tcaccgccaa} 170$ Flic $\mathrm{tcgagcgtctgtcttccggtctgcgtatcaacagcgcgaag} a \mathrm{cgatgcggcaggtcaggcgattgctaaccgttttaccgcgaa} 170$ 180
1 200 220 240
1

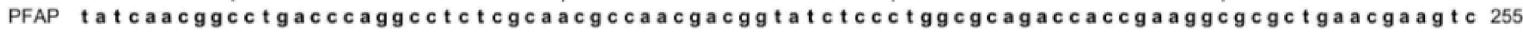
FDP $\mathrm{tat} \mathbf{c a a c g g c c t g a c c c a g g c c t} \mathrm{ctcgcaacgccaacgacggtatctccctggcgcagaccaccgaaggcgcgctgaacgaagtc} 255$

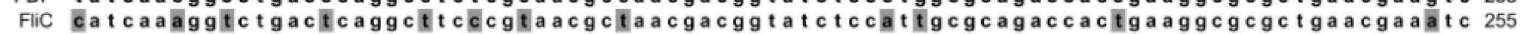
260 280 300 1320 340

PFAP a a c a caacctgcagaacatccgtcgtctgaccgtacaggcacagaacggctctaactcctccagcgacctgcagtccatccagg 340 FDP a c gaca acctgcagaacatccgtcgtct $\underset{360}{1}{ }_{30}$

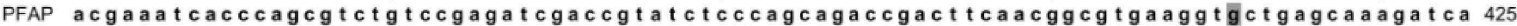
FDP acgaa tcacccagcgtctgtccgagatcgaccgtatctcc agcagaccgact tcaacggcgtgaag tactgagcaaagatca 425

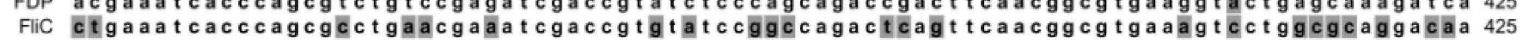
440 460 480 500

PFAP gaagctgaccatccaggt tggegccaacgacggtgaa accatcgatatcgatctgaaaaacatcaacgcacagagcctgggcctg 510 FDP

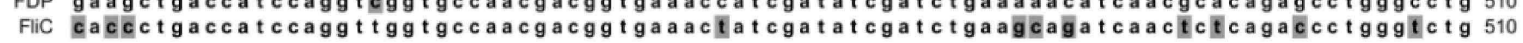
520 540 560 580

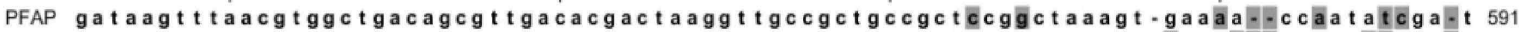

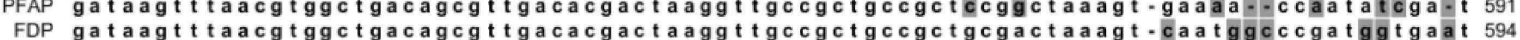

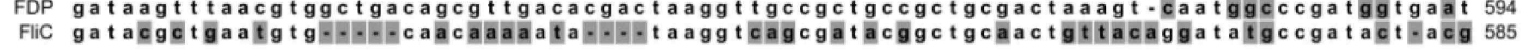
600 620 660

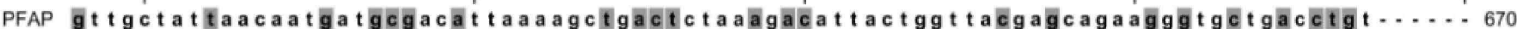

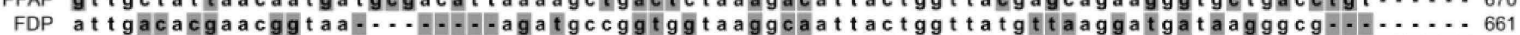

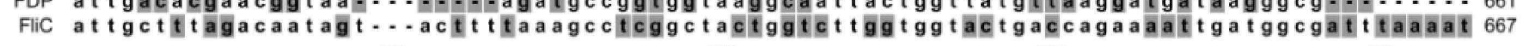
700 720 740 760

PFAP .................... FDP ........................

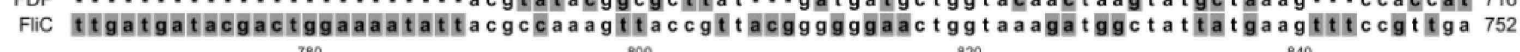
780 800

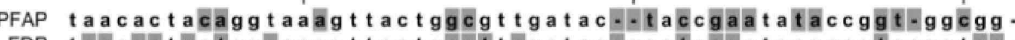

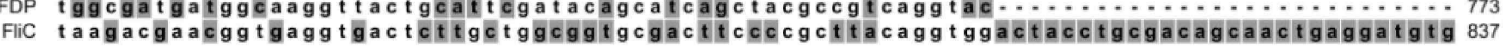

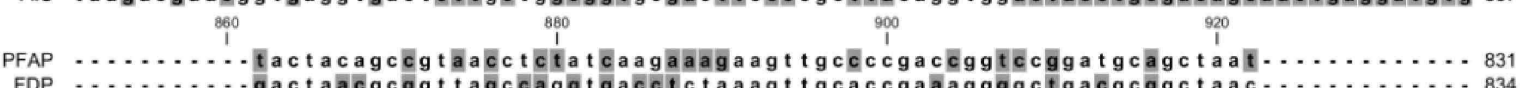

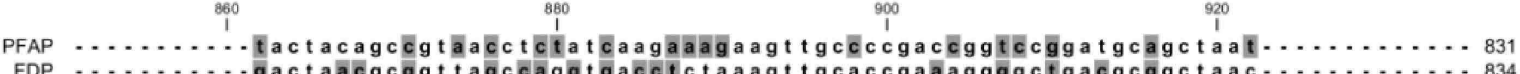

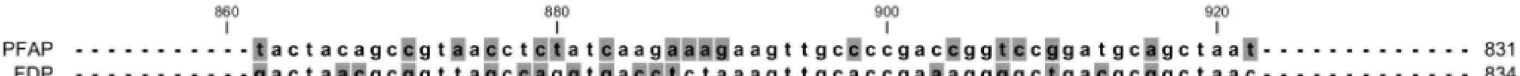
FDP …....... Flic aaaatgtacaagt tgaatgctgatt 940
1

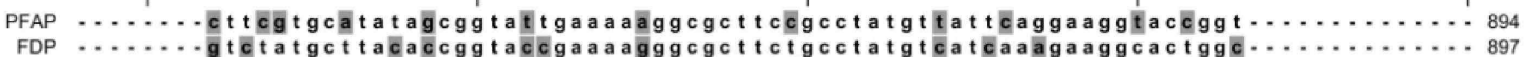

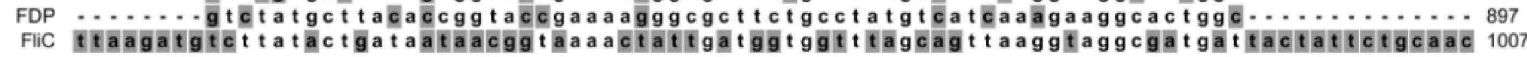

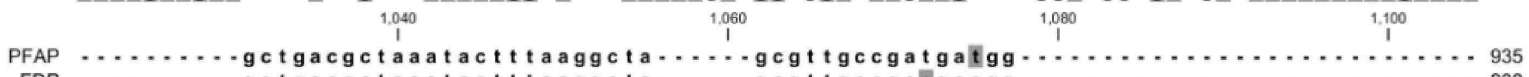
FDP .......... Flic tcaaataajatggt $\mathrm{acc}$ a

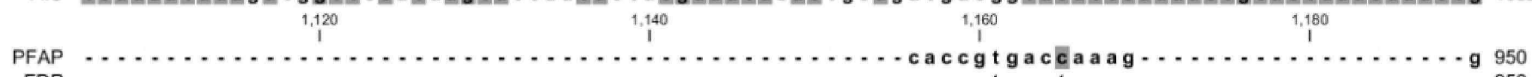

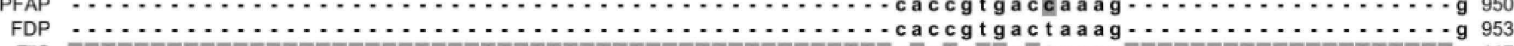

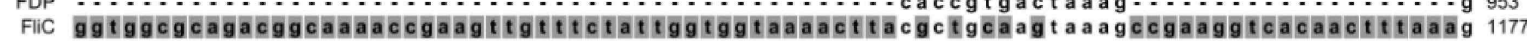

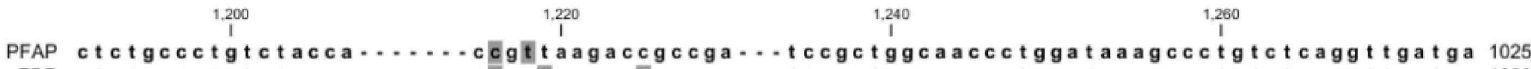
FDP ctctgccctgtctacca...... - . Flic cacagcctgatctggcggaagcgctgctacaaccaccgaaacc c ctgcagaaattgatgctgctt tgcacaggt tgacac 1262 $\begin{array}{ccc}1,280 & 1,300 & 1\end{array}$

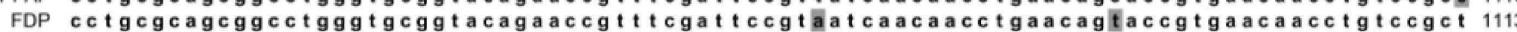
Flic gttacgttctgacctgggtgcggtacagaaccgttcaactccgctattaccaacctgggaacaccg taacaacctgact 1,380 1,400 1,420 1,440

PFAP $\mathrm{tcccgttcacgtat} \mathrm{caggacgctgactacgcgaccgaagtgtccaacatgagccgtgcgcagatcctgcagcaggccggtacct} 1195$ FDP $t \mathrm{cccgttcacgtat} t \mathrm{caggacgctgactacgcgaccgaagtgtccaacatgagccgtgcgcagat} c \mathrm{ctgcagcaggccggtacct} 1198$ Flic gc c c tagccgtatcgaagattccgactacgcgaccgaagt t c caacatgtctcgcgcgcagat tctgcagcaggccggtacct 1432 1,460 1,480 1,500

PFAP ctgtactggcccaggctaaccagt ctacc cagaacgtcctgtctctgctgcgt taa 125

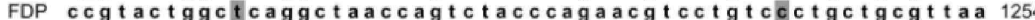

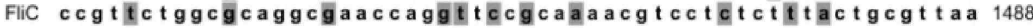

Fig. 4. Alignment of E. tarda CK41 flagellin protein with its homologues. Gray box means does not identical amino acid. PFAP, sequence of E. tarda Putative E. tarda Flagellin Associated Protein; FDP, sequence of E. tarda Flagellin Domain Protein; FliC, sequence of $S$. typhimurium filC. 

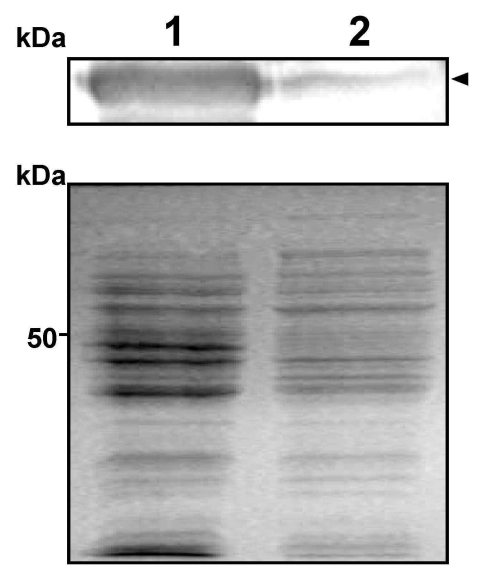

Fig. 5. Expression of PFAP at different $\mathrm{NaCl}$ concentration. Total proteins prepared from $E$. tarda CK41 grown LB broth at different $\mathrm{NaCl}$ concentration were subjected to SDS-PAGE analysis on $12 \%$ polyacrylamide gel. Separated proteins were visualized by Coomassie staining (lower panel). Proteins were subjected to immunoblot analysis as described in Materials and Methods with anti-E. tarda PFAP sera produced in rabbit diluted 1:400 (v:v) (upper panel). Lanes; 1, E. tarda CK41 grown under $1 \% \mathrm{NaCl}$ concentration; 2, E. tarda CK41 grown under $3.5 \% \mathrm{NaCl}$ concentration. Black arrow head indicates PFAP protein.

\section{감사의 글}

이 연구는 국토해양부 해양생명공학기술개발사업 '해양극 한생물분자유전체연구단' 과제에서 지원되었습니다.

\section{References}

1. Altinok, I. 2001. Effects of low salinities on Flavobacterium columnare infection of euryhaline and freshwater stenohaline fish. J. Fish Dis. 24, 361-367

2. Attridge, S. R. and D. Rowley. 1983. The role of the flagellum in the adherence of Vibrio cholerae. J. Infect. Dis. 147, 864-872.

3. Bertani, G. 1951. Studies on lysogenesis I.: The mode of phage liberation by lysogenic Escherichia coli. J. Bacteriol. 62, 293-300.

4. Bhagwat, A. A., W. Jun, L. Liu, P. Kannan, M. Dharne, B. Pheh, B. D. Tall, M. H. Kothary, K. C. Gross, S. Angle, J. Meng, and A. Smith. 2009. Osmoregulated periplasmic glucans of Salmonella enterica serovar Typhimurium are required for optimal virulence in mice. Microbiology 155, 229-237.

5. Blair, D. F., and H. C. Berg. 1990. The MotA protein of $E$. coli is a proton-conducting component of the flagellar motor. Cell 60, 439-449.

6. Chhabra, G., T. Upadhyaya, and A. Dixit. 2011. Molecular cloning, sequence analysis and structure modeling of
OmpR, the response regulator of Aeromonas hydrophila. Mol. Biol. Rep. Published online.

7. Chng, C. P. and A. Kitao. 2008. Thermal unfolding simulations of bacterial flagellin: insight into its refolding before assembly. Biophys. J. 94, 3858-3871.

8. Chowdhury, M. B. R. and H. Wakabayashi. 1990. Survival of four major bacterial fish pathogens in different types of experimental water. Banglad J. Microbiol. 7, 47-54.

9. Clarke, M. B. and V. Sperandio. 2005. Transcriptional regulation of $f l h D C$ by QseBC and sigma (FliA) in enterohaemorrhagic Escherichia coli. Mol. Microbiol. 57, 1734-1749.

10. Decostere, A. and F. Haesebrouck. 1999. Influence of water quality and temperature on adhesion of high and low virulence Flavobacterium columnare strains to isolated gill arches. J. Fish Dis. 22, 1-11.

11. Gao, H., Y. Zhang, Y. Han, L. Yang, X. Liu, Z. Guo, Y. Tan, $X$. Huang, D. Zhou, and R. Yang. 2011. Phenotypic and transcriptional analysis of the osmotic regulator OmpR in Yersinia pestis. BMC Microbiol. 11, 39.

12. Graf, J., P. V. Dunlap, and E. G. Ruby. 1994. Effect of transposon-induced motility mutations on colonization of the host light organ by Vibrio fischeri. J. Bacteriol. 176, 6986-6991.

13. Kodama, H., T. Murai, and Y. Nakanishi. 1987. Bacterial infection which produces high mortality in cultured Japanese flounder (Paralichthys olivaceus) in Hokkaido. Jpn. J. Vet. Res. 35, 227-234.

14. Samatey, F. A., K. Imada, S. Nagashima, F. Vonderviszt, T. Kumasaka, M. Yamamoto, and K. Namba. 2001. Structure of the bacterial flagellar protofilament and implications for a switch for supercoiling. Nature 410, 331-337.

15. Sambrook, J. and D. William Russell. 2001. Molecular Cloning, 3rd eds. CSHL Press, New York.

16. Shoemaker, C. A., P. H. Klesius, C. Lim, and M. Yildirim. 2003. Feed deprivation of channel catfish, Ictalurus punctatus (Rafinesque), influences organosomatic indices, chemical composition and susceptibility to Flavobacterium columnare. J. Fish Dis. 26, 553-561.

17. Steinum, T., A. Kvellestad, D. J. Colquhoun, M. Heum, S. Mohammad, R. N. Grøntvedt, and K. Falk. 2010. Microbial and pathological findings in farmed Atlantic salmon Salmo salar with proliferative gill inflammation. Dis. Aquat. Org. 91, 201-211.

18. Sun, M., M. Wartel, E. Cascales, J. W. Shaevitz, and T. Mignot. 2011. Motor-driven intracellular transport powers bacterial gliding motility. Proc. Natl. Acad. Sci. USA 108, 7559-7564.

19. Tan, Y. P., J. Zheng, S. L. Tung, I. Rosenshine, and K. Y. Leung. 2005. Role of type III secretion in Edwardsiella tarda virulence. Microbiology 151, 2301-2313.

20. Thune, R., L. Stanley, and R. Cooper. 1993. Pathogenesis of gram-negative bacterial infections in warmwater fish. Annu. Rev. Fish Dis. 3, 37-68.

21. Towbin, H., T. Staehelin, and J. Gordon. 1992. Electrophoretic transfer of proteins from polyacrylamide gels to nitrocellulose sheets: procedure and some applications. Biotechnology 24, 145-149. 
22. Tremblay, J., and E. Déziel. 2010. Gene expression in Pseudomonas aeruginosa swarming motility. BMC Genomics 11, 587.

23. Wang, I. K., H. L. Kuo, Y. M. Chen, C. L. Lin, H. Y. Chang, F. R. Chuang, and M. H. Lee. 2005. Extraintestinal manifestations of Edwardsiella tarda infection. Int. J. Clin. Pract. 59, 917-921.

24. Wang, Q., M. Yang, J. Xiao, H. Wu, X. Wang, Y. Lv, L. Xu, H. Zheng, S. Wang, G. Zhao, Q. Liu, and Y. Zhang. 2009. Genome sequence of the versatile fish pathogen Edwardsiella tarda provides insights into its adaptation to broad host ranges and intracellular niches. PLOS ONE. 4, e7646.

25. Wang, X., Q. Wang, J. Xiao, Q. Liu, H. Wu, L. Xu, and Y. Zhang. 2009. Edwardsiella tarda T6SS component evpP is regulated by $\operatorname{esr} B$ and iron, and plays essential roles in the invasion of fish. Fish Shellfish Immunol. 27, 469-477.

26. Wong, J. D., M. A. Miller, and J. M. Janda. 1989. Surface properties and ultrastructure of Edwardsiella species. J. Cin. Microbiol. 27, 1797-1801.

27. Xiao, J., Q. Wang, Q. Liu, L. Xu, X. Wang, H. Wu, and Y. Zhang. 2009. Characterization of Edwardsiella tarda rpos: effect on serum resistance, chondroitinase activity, biofilm formation, and autoinducer synthetases expression. Appl. Microbiol. Biotechnol. 83, 151-160.

28. Zheng, J., S. L. Tung, and K. Y. Leung. 2005. Regulation of a type III and a putative secretion system in Edwardsiella tarda by EsrC is under the control of a two-component system, EsrA-EsrB. Infect. Immun. 73, 4127-4137.

\section{초록 : 염 농도가 어류 병원체 Edwardsiella tarda의 운동성과 편모발현에 미치는 영향 \\ 유종언 · 박준모 · 강호영* \\ (부산대학교 미생물학과)}

염농도에 따른 E. tarda CK 41 의 운동성을 알아보기 위하여 $1.0 \%$ 와 $3.5 \%$ 의 염농도를 가지는 운동성 측정 배지 에서 집락의 변화를 관찰한 결과, $3.5 \%$ 염농도 조건에서 운동성이 감소하는 것을 확인할 수 있었다. $1.0 \%$ 과 $3.5 \%$ 염농도 조건에서의 생육도를 측정해본 결과 각 염농도 조건에 따른 생균수의 차이는 매우 적은 것으로 보아, 높 은 염농도에서의 운동성의 감소는 생육정체가 아닌 실질적인 운동성의 차이에 의함을 알 수 있었다. 이러한 염농 도에 의한 운동성의 차이가 편모에 의한 것인지를 알아보기 위하여 투과 전자 현미경으로 형태학적 관찰을 해본 결과, $3.5 \%$ 염농도에서는 편모의 형성이 되지 않음을 확인하였다. E. $\operatorname{tard} d$ 는 $\mathrm{PFAD}$ 와 $\mathrm{FDP}$ 두개의 편모 유전자를 가지며 이들간의 아미노산 상동률은 $93 \%$ 로 높은 편이다. 편모의 발현양의 확인을 위하여 $\mathrm{PFAD}$ 특이적인 다클론 성 항체를 제작하기 위하여, PFAD를 과발현시키는 재조합 플라스미드 $\mathrm{pBP793}$ 을 구축하여 대장균 발현시스템으 로 발현시켜 정제한 후, 토끼에서 면역반응을 유도하여 특이 항체를 제작하였다. PFAD 특이적인 다클론성 항체 를 이용한 immunoblot assay 결과, $3.5 \%$ 염농도 조건에서 배양한 $E$. tarda CK41의 경우 $1.0 \%$ 염농도에서 보다 반응하는 면역 활성 단백질 밴드가 낮은 것으로 측정되었다. 이러한 결과를 종합하여 볼 때, 염농도가 높은 해수 환경에서의 운동성의 감소는 $E . t a r d a C K 41$ 의 편모 단백질이 제대로 발현되지 않아 기능적인 편모의 형성이 이루 어지지 않는다는 것을 예증하고 있다. 향후 연구에서 어떠한 메카니즘에 의해 염농도가 flagellin의 발현을 조절하 는지를 밝힐 필요가 있다. 